\title{
Struggling with Social Polarization. Student Financial Support in Romania in the Framework of the Bologna Process
}

\author{
Daniela Alexe, Cezar Mihai Hâj and Bogdan Murgescu
}

\section{Introduction}

Social polarization can put at risk both economic development and the democratic cohesion of societies. Its relation to education is twofold. Economic and social inequalities determine inequalities in terms of access to various education levels, while differences in educational attainment generally help to entrench social divides. Global empirical analyses emphasize the strong negative relationship between inequality and human development: "Inequality in health, education and income is negatively related to the Human Development Indicator (HDI), with the relationship much stronger for education and income" (HDR 2010, p. 58). The consequences of inequality are pervasive for the whole economic and social fabric, and do not spare any society. Discussing the current situation of the United States, Joseph Stiglitz argues that: "we are paying a high price for our inequality, an economic system that is less stable and less efficient, with less growth, and a democracy that has been put into peril" (Stiglitz 2012, p. 9). The risks entailed by inequality are even higher for comparatively smaller and less economically developed societies like Romania.

The education system has a great impact on the social structure, mainly due to its private benefits which accrue to its beneficiaries, particularly at the level of higher education. These benefits have been analyzed and argued by many authors. Thus, in

\footnotetext{
D. Alexe $(\bowtie) \cdot$ C.M. Hâj

Executive Agency for Higher Education, Research,

Development and Innovation Funding, Bucharest, Romania

e-mail: daniela.alexe@uefiscdi.ro
}

C.M. Hâj

e-mail: cezar.haj@uefiscdi.ro

B. Murgescu

University of Bucharest, Bucharest, Romania

e-mail: bmurgescu@gmail.com

(C) The Author(s) 2015

A. Curaj et al. (eds.), The European Higher Education Area,

DOI 10.1007/978-3-319-20877-0_32 
general, employees with a graduate diploma earn more than those without one (Johnstone 2010). Also, education is associated with better health and higher life expectancy. Both researchers (Link and Phelan 1995) and international organizations (OECD 2012) that have investigated the link between education and health have indicated that more educated people tend to live longer, healthier lives. The data also shows that better educated people are more civically active in terms of voting, volunteering, political interest and interpersonal trust (OECD 2012). Other benefits identified by researchers include higher levels of living satisfaction $(+18 \%)$ and so-called non-monetary benefits (Vila 2000), meaning that people with higher education attainment are better parents, support their communities by donations, find a job easier and closer to their expectations, with shorter periods of unemployment.

In central and Eastern Europe, increasing social polarization has been a significant feature of the post-communist transition (Bohle and Greskovits 2012; Romano 2014). Access to higher education has been influenced by social inequalities, as well as the overall system liberalization and the demographics of secondary education graduates. In the first two decades of transition, Romania, as well as almost all post-communist societies, made tertiary education available for all. It also started the process of the massification of higher education which had started some decades earlier in the West. During this phase of rapid quantitative growth, few seemed to pay attention to the disproportionate access to higher education of higher socio-economic groups. However, with the stabilizing or even decrease in student numbers and the subsequent setback of massification, students became a scarce resource for the universities. Thus, it is expected that there will be a growing political interest to increase access to higher education for students from lower socio-economic backgrounds and other groups which have traditionally been underrepresented in higher education.

The main goal of this article is to assess whether the existing student support schemes, as one of the main tools to improve access and participation to higher education, are relevant in terms of public efforts to meet the social need of specific under-represented groups in Romania. Therefore, the article will briefly describe the role of the Bologna Process in promoting the need for national policies aimed at reducing educational inequities and look at ways in which equity in higher education (including access and participation of under-represented groups) can reduce social polarization. We will focus on how different types of scholarships influence young people's decision to enrol in higher education institutions, overcome difficulties during their studies and finally graduate. In this endeavour, besides analyzing the existing literature, the available statistical information and official documents adopted by public institutions, we will also ground our analysis on two original data sources. The first is a quantitative survey of a representative group of 1093 students at 21 Romanian state universities; the second is data collected by the authors from eight universities within the European funded project "Internationalization, equity and university management for a more qualitative Higher Education system (IEMU)", implemented by the Executive Agency for Higher Education, Research, Development and Innovation Funding (UEFISCDI). This latter project aimed to analyze the impact of national equity policies in the 
Romanian higher education and included a number of eight study visits during which university management, members of decision making bodies, academic staff and students were interviewed. The university sample was representative, as the authors targeted different types of institutions (comprehensive universities, as well as higher education institutions specialized in technical, economic, agricultural and medical studies) from different geographical areas.

\section{The Role of the Bologna Process, Equity and Student Support Schemes in Reducing Social Polarization}

The "Social dimension" is one of the main action lines of the Bologna Process. Starting in 2001 with the adoption of the Prague Ministerial Communiqué, ministers committed towards reducing inequities in their respective higher education systems. In Prague, the ministers reaffirmed "the need, recalled by students, to take account of the social dimension in the Bologna Process" (Prague 2001). In the 2005 Bergen Ministerial Communiqué, the social dimension of education was undertaken as a priority for the implementation within the Bologna Process, with the Ministers committing themselves to taking measures for an increased access to higher education. The Bergen document defined the social dimension as including "measures taken by governments to help students, especially from socially disadvantaged groups, in financial and economic aspects" (Bergen 2005); the 2007 London Ministerial Communiqué elaborated on this, specifying that the social dimension of higher education in the context of the Bologna Process was a commitment to the notion that "the student body entering, participating in and completing higher education at all levels should reflect the diversity of our populations" London 2007).

In the most recent Ministerial Communiqué, the priorities set by Ministers include improving national policies to increase the access and attainment of higher education, with a particular emphasis on underrepresented groups with high-risk exclusion. To quote the communiqué: "at the national level, together with the relevant stakeholders, and especially with higher education institutions, we will: strengthen policies of widening overall access and raising completion rates, including measures targeting the increased participation of underrepresented groups.” (Bucharest 2012).

As Schwarzenberger noted: in the absence of policies aimed at reducing the social differences in society, the current trend of higher education is to increase the differences among individuals and not to reduce them (Schwarzenberger 2008). Precisely in order to counteract this trend, ministerial commitments on student support systems have been taken within the Bologna Process in order to better develop the social dimension of higher education (Bucharest 2012). The major aim is to integrate students from underrepresented groups in order to reduce social disparities within the higher education system and, more generally, in society. The ministerial commitments have thus created an international policy environment which perceives student support systems as a pillar for equity in higher education. 
Access, participation and completion of studies by certain categories of students are influenced by poverty, rural isolation, parents' low education levels, disabilities or an ethnic minority status. In those places where universities charge tuition fees, limited family income can also be a barrier to access higher education. In this regard, one of the most important tools impacting on the behaviour of higher education institutions in terms of national equity policies implementation is the funding mechanism.

Funding of higher education is generally covered by some mixture of public and private (students, alumni, donors, etc.) sources. State higher education funding translates either into direct support to universities or indirect support in the form of resource transfer to students or their families (Salmi and Hauptman 2006). Moreover, public funding can be directed to cover two main types of costs: those related to institutional provision (academic staff salaries, administrative costs, etc.) and students' living costs.

Living costs (in addition to tuition fees) represent other types of expenses for accessing, progressing and completing a study program and are generated mainly by the need for accommodation throughout the study period, meals, books, equipment, and other personal expenses/other administrative fees charged by the university (registration fees, final exams and re-examination fees, library access etc.). Generally, they are not covered by the tuition fees. Many of these living costs exist for all levels of education (from kindergarten to higher education). For young people coming from low-income families, the effort to progress within the education system for a long period of time (it takes 15 years or more of formal education to graduate from university) is considerably higher than it is for other social categories. Basically, even if children are motivated to continue their studies, the poorer families' financial situation acts as a barrier in terms of access to higher education.

There exists a variety of ways in which national policies and institutional instruments can be designed to offset these barriers. Usually, the choice of instrument says something about the different ways in which the State views the role of students in society. Schwarz and Rehburg identify four such view of students: students as investors (in the UK), as dependent family members (Italy), as teenagers in training (France) or as citizens with their own responsibilities (Norway) (Schwarz and Reheburg 2004). Although these categories are not mutually exclusive, different financing support systems for students were designed to promote social equity in higher education, such as study loans, study vouchers-directly related to the decision of the student, bursaries and scholarships and tax benefits for families with students.

Bursaries and scholarships as non-repayable forms of aid, are equity policy instruments aimed at providing financial support to cover the living costs associated with the educational process, other than tuition fees, i.e. expenses related to accommodation, meals, transportation, teaching materials and others. The student financial support systems have different names used in different higher education systems and countries. For example, the term "scholarship" is used in some higher education systems to define solely the money given to students on merit criteria, 
while other countries use this term for all types of public aids, including need based aid. The same applies for other terms such as "bursary", "aid", "grant" a.s.o. In the present article on the Romania case study, the term "scholarship" will be used to express the public money distributed to students with the distinction of "merit scholarships" for money given on academic performance criteria and "need based aid" for money given on social criteria.

In Europe, scholarships can be provided directly by the government, through a specialized agency, as it happens in France and in most Francophone countries, or by transferring the management responsibility for scholarship funding to the higher education institutions (i.e. Hungary, Lithuania, Poland, Portugal). Salmi and Hauptman note that the trend for centralized regulation of scholarships increases with higher public contribution. The criteria for scholarships allocation are determined either by an assessment of social needs (in this case being policy instruments of equity) or by students' academic merit. While the latter are mainly policy instruments to encourage performance, the scholarships awarded on the basis of social need aim to widen participation in higher education for social groups that traditionally do not have access to such education.

\section{Equity in the Romanian Higher Education System}

As per the Bologna Process commitments (London 2007), the equitability of a higher education system needs to be measured not only in terms of its ability to provide access to under-represented groups, but also in its ability to allow them to participate in the system and graduate from it.

To a large extent, access to higher education is determined by the structure and number of graduates in secondary education. Thus, equity in higher education is a product of influences on young students much earlier in the educational pipeline. Access to higher education is not only determined by pupils' intellectual abilities and efforts, but also by other factors such as: access to good primary and secondary schools, competent teachers, family support and motivation for a continued educational path or financial ability to afford tutoring. Consequently, universities' overreliance on student achievement for admission to higher education (or for providing financial support) may raise a number of issues regarding equity.

Data provided by the National Institute of Statistics (NIS) and the Institute of Education Sciences report on the state of education (ISE 2011) show that in Romania the degree of inclusion in education for all age categories increased until 2008. From then onwards, the degree of inclusion begins to decrease, in other words, a higher number of pupils dropped out of school or were no longer found in the formal education system (Table 1).

Moreover, results for Romania in the 2011 Trends in International Mathematics and Science Study (TIMSS) and Progress in International Reading Literacy Study (IEA 2012b) show important performance differences on the basis of pupils' living background (rural/urban) or economic status. For example, $65 \%$ of PIRLS-tested 
Table 1 Degree of inclusion of the school age population (\%), NIS, 2014

\begin{tabular}{l|l|l|l|l|l|l|l|l}
\hline Age & 2005 & 2006 & 2007 & 2008 & 2009 & 2010 & 2011 & 2012 \\
\hline 3-6 years & 79.65 & 78.84 & 79.2 & 79.8 & 81.0 & 81.8 & 82.0 & 86.1 \\
\hline 7-10 years & 92.56 & 93.25 & 94.5 & 97.1 & 97.3 & 95.7 & 93.6 & 93.1 \\
\hline 11-14 years & 78.86 & 79.41 & 81.1 & 89.4 & 94.3 & 94.3 & 93.1 & 91.7 \\
\hline 15-18 years & 81.56 & 81.67 & 83.0 & 88.5 & 88.8 & 86.2 & 84.2 & 81.9 \\
\hline Over 19 years & 51.77 & 59.59 & 72.5 & 78.3 & 76.4 & 70.1 & 59.7 & 53.7 \\
\hline
\end{tabular}

students come from cities with 15,000 inhabitants or less, and their average performance is 33 points below the international average (IEA 2012a). For $21 \%$ from PIRLS-tested students from cities with 100,000 or more inhabitants, the average performance is 31 points above the international average. The performance differences are also correlated with the pupils' access to resources at home. For example, in Mathematics, the $10 \%$ tested pupils designated as having better "home resources" $(10 \%)$ scored 27 points above the international average, while the $19 \%$ of pupils with fewer "home resources" performed 25 points below the international average. These figures underline that equity in higher education is strongly influenced by equity in primary and secondary education, and policies addressing these issues should take into consideration the wider picture.

Given that graduating from high school and passing the baccalaureate exam is mandatory for accessing higher education, it is extremely important to analyze the characteristics of the high school graduate population. Figure 1 shows that the number of students finishing secondary school and taking the Baccalaureate exam

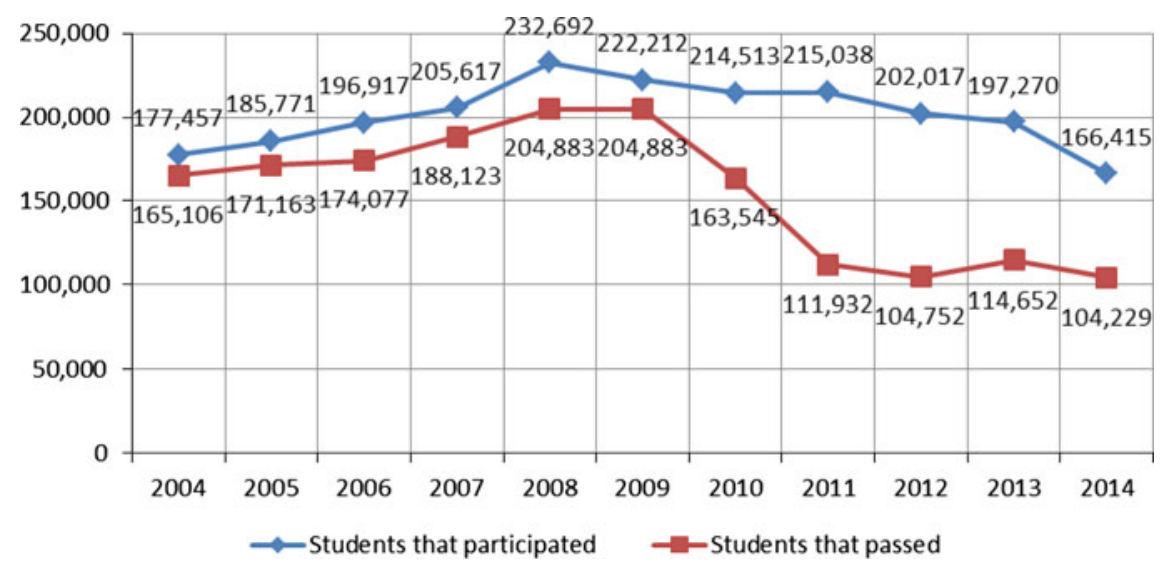

Fig. 1 Evolution of the number of candidates enrolled in the baccalaureate exam and the number of candidates who passed the baccalaureate exam after both sessions, Ministry of National Education (MNE), 2014 


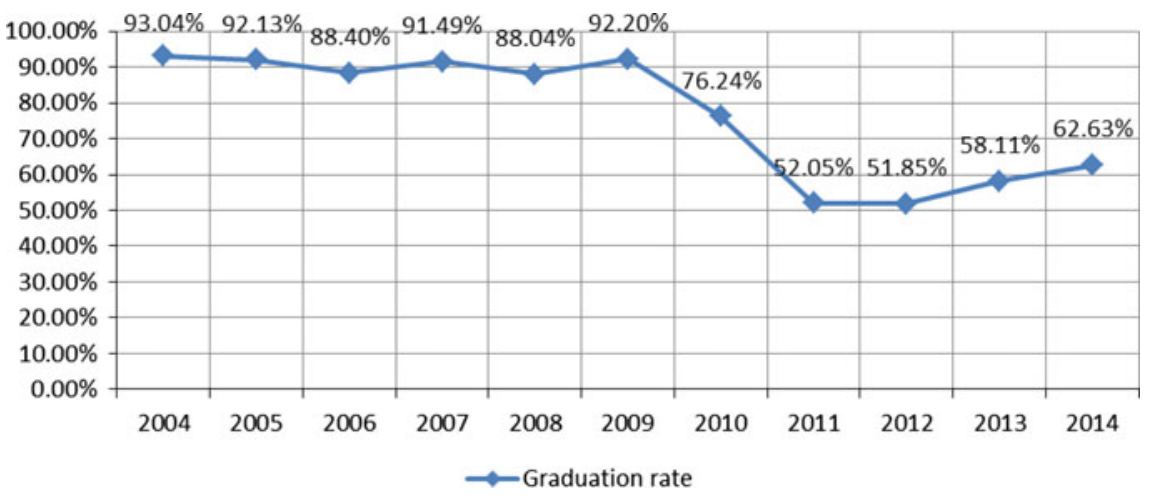

Fig. 2 Evolution of the baccalaureate exam success rate, MNE, 2014

decreased by nearly $29 \%$ between 2008 and 2014 . This is mainly a demographic change, due to the fall in the national birth rate during the transition from communism. In addition to this, there was a precipitous drop in the pass rate on the baccalaureate after 2009, after the introduction of both a more difficult exam and stricter invigilation procedures. However, as Fig. 2 shows, since 2012 this trend has reversed and exam pass rates have begun rising again; however, this increase is not enough to offset the continuing declines in student numbers due to demographics.

Both the demographic trend and the baccalaureate pass-rate trends have combined to significantly shrink decreasing overall student numbers at the tertiary level. Figure 3 shows the evolution of the student population in recent years. Overall, student numbers are now at less than half where they were in 2007, but this drop has not been spread equally across sectors. Among private institutions, enrolment has fallen by slightly more than $80 \%$ while among public institutions it has been a less drastic (but still enormously significant) $32 \%$.

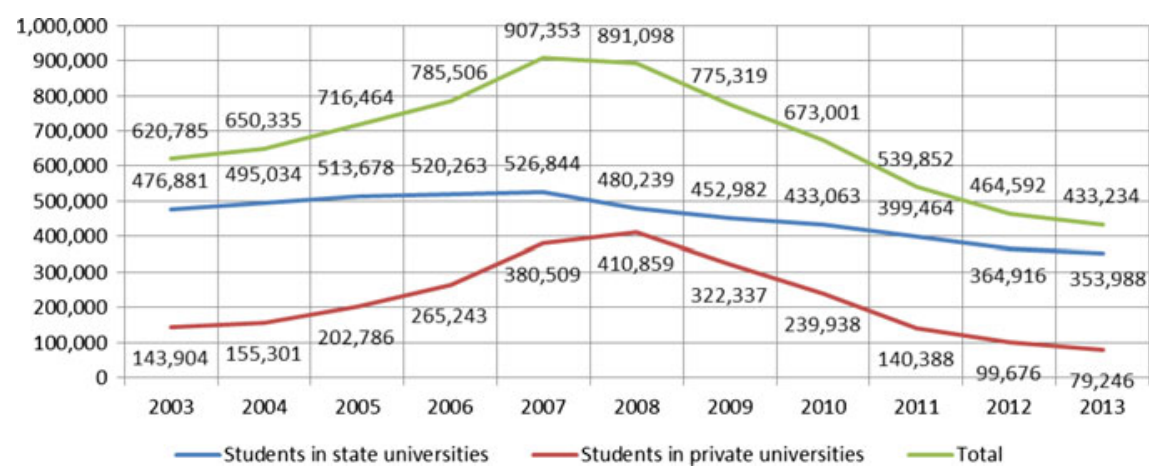

Fig. 3 The number of undergraduate students from state and private universities, NIS, 2013 


\subsection{Social Disparities Among Students}

While the Bologna Process commitments (Louvain 2009) require clear targets and plans for the access of underrepresented/disadvantaged groups in higher education, Romania does not currently have a strategy with explicit targets or implementation measures. That being said, several official documents identify those groups considered under-represented. The 2012 national Bologna Process implementation report lists a number of such groups, including Roma youth, orphans, youth from low-income families, youth from rural backgrounds, students with high socio-economic risk or socially marginalized, ethnic Romanians living abroad (Romanian Government 2012). In addition to these categories, the Education Law also mentions students with disabilities, and the National Reform Plan mentions children whose parents work abroad.

As in most countries worldwide, there is a strong correlation in Romania between socio-economic background on the one hand, and higher education participation/completion on the other. However, there are very few national studies which examine the distribution of students according to family income on an empirical basis. One dataset provided by the Romanian universities ${ }^{1}$ in 2011 indicates that the percentage of students from disadvantaged socio-economic backgrounds (groups defined by the Education Law no. 1/2011, Art. 205, letter 6) was about 10-11\% of total student population over the period 2005-2010. Also, a World Bank study points out that of the $20 \%$ (quintile) of young people from the richest households (aged 25-29 years) in Romania, over 50\% hold a tertiary degree, compared with only $5 \%$ of the $20 \%$ (quintile) of young people from the poorest households in Romania (World Bank 2011). These data show that participation rates of students from low-income families are still low compared to those of students from high-income families.

Another underrepresented group in higher education is that of the students coming from rural areas. Often, this group overlaps with the students from low-income families; NIS shows that the average income per household in rural areas was $29.3 \%$ lower than in urban households in 2014. This, naturally, leads to disparities at the secondary level. Failure rates on the baccalaureate exam, for instance, are significantly higher in rural areas $(47.4 \%)$ than they are in urban ones (33\%). This disparity then grows at the post-secondary level. According to NIS data for 2011, $55 \%$ of the Romanian population resided in urban areas and $44 \%$ in rural areas; yet, at the beginning of the academic year 2011-2012, the distribution of students by residence area was $75.68 \%$ in urban areas and $24.32 \%$ in rural areas (National Institute of Statistic-Tempo-online database, 2014).

\footnotetext{
${ }^{1}$ Data provided by universities in the process of university classification and study program ranking, 2011.
} 
The lack of effective integration policies for rural youth in higher education generates social inequities in the distribution of academic qualifications. Thus, in $2009,7.1 \%$ of young people aged 25-29 years residing in rural areas graduated from a higher education institution, compared to $33.4 \%$ residing in urban areas (World Bank 2011). Another World Bank report indicates that: "The difference observed in the rate of urban-rural denotes significant differences in education and hides the lack of access of vulnerable groups. Differences in performance can be attributed to inequity and inefficiency of resource allocation." (World Bank 2007). In this regard, we also need to take into account the particularities of the Romanian education system, where educational establishments (schools, universities) are concentrated in urban areas, thus generating additional costs for rural areas families (Voicu and Vasile 2010). The discrepancy between rural and urban families is even more visible if we consider that the category "rural families" also includes a small number of affluent sub-urban rural communities, which often have higher revenues than the urban population, thus contrasting heavily with the majority of the rural population. Romanian statistics do not break down the student population according to the type of originating rural background, but the authors of this paper postulate that in fact about half of the higher education students with rural background come from affluent sub-urban communities (which represent less than $10 \%$ of the total rural communities in Romania), leaving thus the majority of the rural population even more underrepresented in the student population than the national statistics would suggest.

Young people with disabilities are considered a disadvantaged group both internationally and in Romania. At the end of 2012, the percentage of people with disabilities in the total Romanian population was $3.66 \%$, according to NIS. In 2011 , from the total population with disabilities, only 6669 people were registered as students with disabilities in high schools and universities, although $2.6 \%$ were of school age (15-24 years).

According to official data provided by the General Directorate for the Protection of Persons with Disabilities, the population with disabilities is over 679,765 people, out of which over 17,000 are institutionalized. However, because the definition of disability is a contested and inconsistent one, the data on the participation of disabled students varies considerably by source. According to the EUROSTUDENT data for Romania, the percentage of students with physical disabilities and chronic illnesses out of the overall student population is $1.10 \%$ (Eurostudent 2008), while the data provided by universities in the classification process of 2011 indicated that only $0.07 \%$ of all students are included in this category (Fig. 4).

Beside the above analyzed underrepresented groups in higher education, there are other vulnerable groups as well, but no in depth analysis could be performed due to the lack of reliable data (for example, Roma students). 


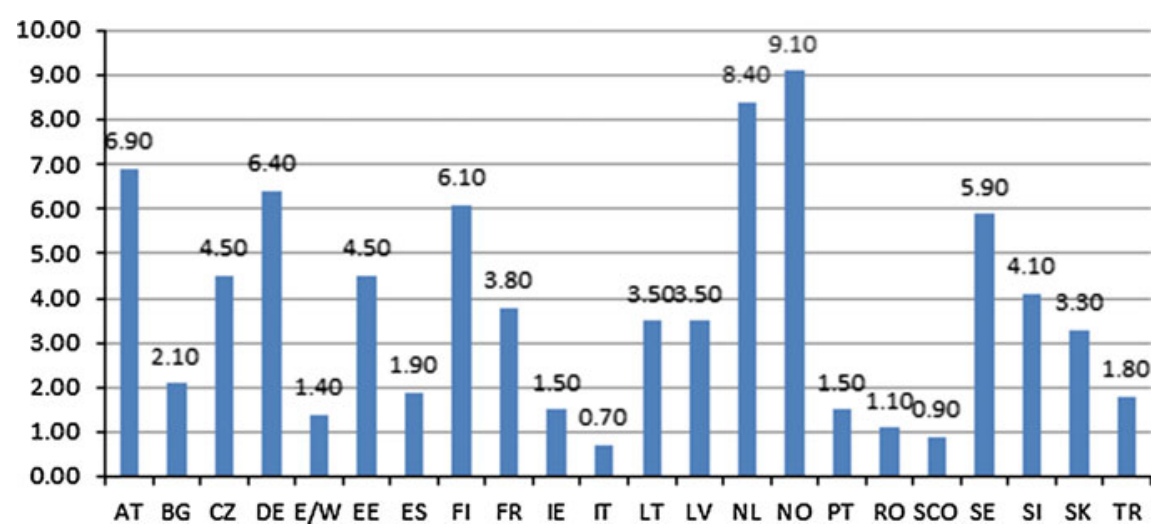

Fig. 4 Students with physical disabilities and chronic illnesses out of the overall student population, for EU countries (Eurostudent 2008)

\section{Do Student Support Systems (E.G. Student Scholarships) Increase the Level of Equity in Higher Education?}

There are a number of national policies in place to increase the access and participation of under-represented groups in higher education. However, before examining these, it is worth summarizing how access to public universities is regulated.

The first legal condition for all candidates is to pass the national examination (baccalaureate). Afterwards, they can choose to either enrol in a private university and pay tuition fees, or in a public university, where they can benefit from a free (state-financed) place or pay tuition fees, based on their entrance grade. At university level, the state-financed study places are distributed to the top students at the end of the admission examinations organized by universities according to a general framework, approved by the Minister of Education. When calculating the general admission grade, the universities can also use as criteria the baccalaureate exam grades or grades from university-organized admission exams which some institutions run independently of the state exam (for testing knowledge and cognitive capacities). Several groups of students can obtain specially-financed free study places: Roma students, students from foster homes or ethnic Romanians from abroad. In all cases, the distribution of public funds to cover the students' educational costs is merit-based.

Regarding the participation of under-represented groups, the main policies in place for their financial support and/or integration, outside the need based aid, are: subsidies for student dorms and canteens, subsidies for local and national transportation and free medical and psychological assistance. 


\subsection{The Romanian Student Support System: The Case of Student Scholarships}

The Romanian student aid system was first regulated in the late $1990 \mathrm{~s}^{2}$ and its provisions were confirmed with some minor changes by the more recent Education Law (1/2011). ${ }^{3}$ There are two main types of student scholarships, one merit-based and the other one based on social criteria, i.e. need-based aid. While the general criteria for awarding scholarships are regulated nationally, the system allows each university to define and implement their own additional criteria. All legal documents concerning the student aid system (National Education Law, secondary legislation) reiterate the following major objectives:

- for merit-based scholarships, to encourage learning, academic performance, and excellence;

- for need-based aid, to secure financial support for students from low income families.

According to the Education Law, the same student may receive both types of scholarships, if they meet the eligibility criteria. These scholarships are awarded for an entire academic year and, with a few exceptions, that includes the entire calendar year where medical aid, academic performance scholarships and aid for orphans are concerned.

The monthly lump sum provided by the government to universities for the purpose of scholarships is calculated by multiplying the fixed amount granted by the government per budgeted student place (currently 69 lei, i.e. approx. 16 Euro) by the number of budgeted places allocated for that university. Universities can supplement the scholarship fund from their own income. At national level, the scholarship fund is not divided into separate funds for need-based aid and merit scholarships; rather the universities themselves decide how the funds are divided between these categories, as well as the amounts and the number of available scholarships. Institutional behaviour in allocating these funds between merit and need-based awards may therefore be seen as a proxy for the importance given to equity by Romanian universities.

Before discussing how Romanian universities allocate the scholarship fund for different policy objectives, some comments about the perceived hierarchy between the need-based aid and the merit scholarships are perhaps in order. Firstly, one of the most common misconceptions recorded during our interviews with key stakeholders at universities is that the need-based awards are somehow second-rate scholarships and should be of lower value than the merit scholarships. This is

\footnotetext{
${ }^{2}$ Order no. 558/1998 on amendments to Annexes 1 and 2 of Order no. 455/1997 establishing general criteria for scholarships and other forms of support for pupils, students and trainees in public education, day courses. For the general context of setting up this system, see Proteasa and Miroiu (2013, pp. 177-180).

${ }^{3}$ Education Law 1/2011, art. 12, paragraphs (2) and (4), art. 223, paragraphs (9), (10), (11).
} 
despite the fact that the Education Law 1/2011 clearly states that the social scholarship should cover minimum subsistence costs, i.e. for housing in a dormitory and for three basic meals daily. In consequence, though the $\mathrm{CNFIS}^{4}$ annually calculates a national monthly standard for need-based aid (the latest calculation is 575 lei or about 130 Euro per month), in fact universities provide much smaller awards varying between 25 and $60 \%$ of the national standard. Their argument for keeping the awards value low is that to provide higher sums would imply that the awards were of greater importance and prestige than merit scholarships. To raise need awards to the required level would require them to also increase the size of merit awards which, considering the limited amount of money received from the state, would only allow for a very small number of students to receive merit scholarships.

Although there is a trend at the level of national student federations towards an increased social sensitivity (Proteasa and Miroiu 2013), the hierarchy between need- and merit-based aid has not yet changed significantly, and the pattern established in the late 1990s has remained relatively constant over time. So, while meritocracy and social support are not necessarily dichotomous (Haj 2014), the current scholarship system forces universities to choose between rewarding academic performance and supporting the low-income students. The issue of prioritizing equity on the public agenda was analyzed by Koen Geven, who links this attitude of academics to communist reminiscences: "it is either a non-issue or a communist issue" (Geven 2012), an attitude which creates a difficult political environment in which to promote need-based aid.

\subsection{Does the Needs-Based Aid Fulfil the Equity Aim?}

In 2013, the 44 public universities that reported data to the CNFIS allocated, on average, $15 \%$ of their scholarship funds for need based aid, with the rest being allocated to merit scholarships. This suggests that although there is a concern for students with special needs, the desire to boost academic performance and reward merit students remains institutions' top priority. Furthermore, the data reveal the desire of academic communities to distribute the available public funds based on student abilities at the expense of their social needs.

At the eight institutions where site visits had been conducted as part of the IEMU project, the national trend and percentages were mirrored. With respect to the evolution of the distribution between the two types of scholarships, one could observe a small shift in allocations in favour of need-based aid in recent years. Interviews with university representatives indicated that one of the main reasons for this shift is the growing number of student requests for social aid. Nevertheless, universities manage need-based student aid very carefully for fear of abuse; a

\footnotetext{
${ }^{4}$ Further in the article we will use CNFIS for the National Council for Higher Education Funding.
} 


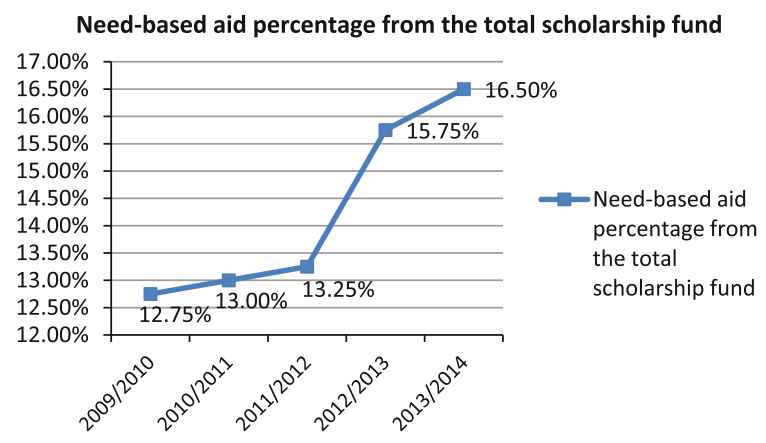

Fig. 5 Evolution of the percentage allocated for need based aid from the overall scholarship fund for the visited universities, bachelor level (the authors)

particular concern is that students whose parents work abroad may declare no official income in Romania in order to access aid regardless, while in fact receiving substantial parental assistance. This concern was embraced by all university representatives, including students and student representatives at local and national level (Fig. 5).

\subsection{How Many Students Are Supported by the Scholarship System?}

The data show that in 2013 there were 389,037 students at bachelor and master level in public universities, which implies that the national budget for scholarships is approximately 6 million Euro per month. Taking into consideration that, on average, $15 \%$ of the scholarship budget is allocated for need based aid, and knowing the calculated average amount of a need based scholarship (50.33 Euro), it means that, at national level, approximately 17,975 students benefit annually from this type of financial support. This makes it one of the largest and most expensive student support policies implemented in Romania, covering almost $4.62 \%$ of the state subsidized students.

At our eight case-study institutions, the percentage of students who received need based aid in 2013 was $4.23 \%$ of the total number of subsidized students, which more or less confirms the national estimate with respect to need-based aid. Moreover, the existing data also showed that this percentage increased in the last years at most institutions. However, among the case-study institutions, there were two where the percentage decreased considerably, proving that behaviour varies from one university to another.

Mere knowledge of how these funds are allocated between the two types of scholarships is not enough to evaluate the impact of this policy. Since scholarship amounts are established at university level, each institution faces a choice between 


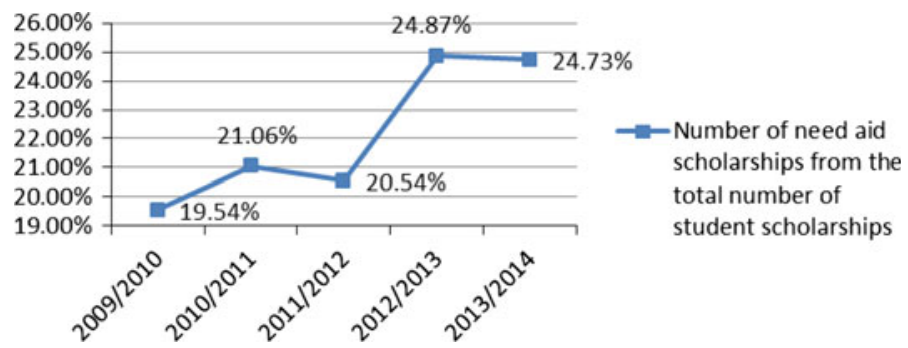

Fig. 6 Need-based awards as a percentage of total awards, 2009-10 to 2013-14 at eight case-study universities

offering a large number of small scholarships and a small number of big scholarships. The impact of these two approaches can differ greatly, as in one case the amount of money allocated can be insufficient to cover student costs, and in the other the number of allocated scholarships might be too small to help an under-represented group as a whole.

At our smaller sample of eight universities, the ratio of need-based vs merit-based awards has increased from less than 1:4 in 2009/2010 to almost 1:3 in 2013/2014 (Fig. 6).

At national level, according to the National Council for Higher Education Funding (CNFIS 2013), the 2013 average value of need-based awards was around 225 lei (56 euro), while the merit scholarships varied between 271 lei (61 Euro) and 486 lei (109 Euro), depending on the type of merit scholarship. In 2014, CNFIS recommended 575 lei as the average value for need-based aid.

At the level of individual universities, one can see that these amounts have increased in almost all universities over the last few years, but at the same time the university representatives confirm the CNFIS argument that need-based aid does not cover the minimum expenses for meals and accommodation: "Unfortunately, scholarships are calculated based on the money the universities receive, not on the real cost for meals or accommodation" (University representative).

Table 2 shows that, while universities have been increasing the size of the bursary, the increases have effectively only mirrored inflation.

Table 2 Evolution of the average amount of need based aid (euro)

\begin{tabular}{l|l|l|l|l|l}
\hline & $2009 / 2010$ & $2010 / 2011$ & $2011 / 2012$ & $2012 / 2013$ & $2013 / 2014$ \\
\hline $\begin{array}{l}\text { Average amount of need } \\
\text { based aid as decided by } \\
\text { universities }\end{array}$ & 45.8 & 46.7 & 48.8 & 53.6 & 55.28 \\
\hline $\begin{array}{l}\text { Value of 2009/2010 } \\
\text { bursaries after inflation }\end{array}$ & 45.8 & 48.59 & 51.41 & 53.16 & 54.86 \\
\hline
\end{tabular}




\subsection{Who Are the Students Receiving Need Based Aid?}

According to the Education Law, the following student categories are eligible for need based aid: orphan students, orphanage students or foster care students who do not have income, students from low income families, and students with specific diseases. Also, according to the same Law, the minimum amount of a need based scholarship should be proposed annually by CNFIS, taking into account that a scholarship must cover the minimum costs for meals and accommodation.

Looking at the characteristics of the student population receiving need based aid, we can notice that, from our sample of 1093 students receiving scholarships, only $32 \%$ have a rural background; of these, $45.36 \%$ received need based aid (Table 3 ).

In terms of accommodation, most students receiving need-based aid live in student dormitories ( $56.7 \%$ ), which can be explained by the fact that more than half of them come from the first two poorest income quintiles (Tables 4, 5).

It is clear from this table that need-based aid does not cover adequately students' needs, as a large part of their income still comes from the family and/or partner. $60 \%$ of the questioned students with a need based scholarship receive more than $50 \%$ of their income from their families and partners. Thus, students benefiting from need based aid still pose a great financial burden on their families (Table 6).

\subsection{Minimum Living Costs for Students}

In order to graduate from a higher education program, socially-vulnerable students need financial support to cover living costs. Yet, as already mentioned, monthly living costs are much higher than the need-based aid provided by universities. On

Table 3 Living background of the students receiving scholarships

\begin{tabular}{l|l|l}
\hline & Urban background (\%) & Rural background (\%) \\
\hline Respondents & 70 & 30 \\
\hline Students receiving need based aid & 54.64 & 45.36 \\
\hline Students receiving merit based aid & 70.37 & 29.63 \\
\hline
\end{tabular}

Table 4 Living situation of the students receiving need based aid

\begin{tabular}{l|l|l}
\hline $\begin{array}{l}\text { Living } \\
\text { situation }\end{array}$ & Number of respondents & $\begin{array}{l}\text { Percentage } \\
(\%)\end{array}$ \\
\hline Home & 17 & 17.53 \\
\hline Rent & 22 & 22.68 \\
\hline Student dorms & 55 & 56.7 \\
\hline Other & 3 & 3.09 \\
\hline Total & 97 & 100 \\
\hline
\end{tabular}


Table 5 Income situation of the students that receive need based aid

\begin{tabular}{l|l|l|l}
\hline $\begin{array}{l}\text { Income } \\
\text { quintile }\end{array}$ & $\begin{array}{l}\text { Respondents } \\
(\%)\end{array}$ & $\begin{array}{l}\text { Students who received a merit } \\
\text { scholarship (\%) }\end{array}$ & $\begin{array}{l}\text { Students who received a } \\
\text { need based aid (\%) }\end{array}$ \\
\hline 1 & 5.58 & 4.26 & 17.5 \\
\hline 2 & 19.85 & 18.46 & 32.9 \\
\hline 3 & 39.80 & 41.58 & 35 \\
\hline 4 & 30.28 & 31.03 & 12.37 \\
\hline 5 & 4.48 & 4.67 & 2 \\
\hline Total & 100.00 & 100.00 & 100.00 \\
\hline
\end{tabular}

Table 6 Proportion of need-based aid recipients' income received from families and partners

\begin{tabular}{l|l|l|l|l|l|l|l|l|l|l|l}
\hline $\begin{array}{l}\% \text { of students } \\
\text { income from } \\
\text { family and } \\
\text { partner }\end{array}$ & $\begin{array}{l}0- \\
10 \%\end{array}$ & $\begin{array}{l}10- \\
20 \%\end{array}$ & $\begin{array}{l}20- \\
30 \%\end{array}$ & $\begin{array}{l}30- \\
40 \%\end{array}$ & $\begin{array}{l}40- \\
50 \%\end{array}$ & $\begin{array}{l}50- \\
60 \%\end{array}$ & $\begin{array}{l}60- \\
70 \%\end{array}$ & $\begin{array}{l}70- \\
80 \%\end{array}$ & $\begin{array}{l}80- \\
90 \%\end{array}$ & $\begin{array}{l}90- \\
100 \%\end{array}$ & Total \\
\hline$\%$ of students & 4.49 & 7.86 & 4.49 & 4.49 & 19.10 & 7.86 & 4.49 & 13.48 & 11.23 & 22.47 & 100 \\
\hline
\end{tabular}

average, minimum accommodation costs in student dormitories from 44 state universities amount to 126 lei (28 Euro), while the average daily cost for meals is 14.8 lei (3.3 Euro). In this context, a student needs approximately 575 lei (130 Euro) per month to cover the minimum living costs.

In theory, student dormitory fees should cover maintenance costs. One would therefore expect that these would vary from region to region, with cost rising in line with the level of economic development. However, this does not appear to be the case; in fact, in many cases, students' living costs are higher in the less developed regions of the country than they are even in Bucharest. This leads us to suspect that accommodation costs are rather more directly influenced by the managerial skills of the university administration and the universities' perceived importance for investments in student dormitory modernization and cost reduction strategies. In any case, since the monthly minimum financial need of students for meals and accommodation is 130 Euro, it is clear that there is no university where need-based aid covers the relevant costs.

\section{Conclusions}

The article starts from the assumption that economic and social inequalities in society determine inequalities in access to various levels of education and in turn, these discrepancies in participation to education lead to more social inequalities in 
society at a later stage. At European level, the achievement of equity through fostering access, progress and success of young people from vulnerable groups is at the heart of the Bologna Process' "social dimension" theme. This is one of the few Bologna action lines where member states committed themselves to clear measures, such as developing plans and policy instruments, as well as establishing clear national targets. For higher education, student support systems are considered by the Bologna Process and EU policies alike as a key element to foster equity in higher education and social cohesion more broadly.

Obviously, a large part of the inequities of the student population at Romanian universities is determined by the significant discrepancies of eligible candidates to higher education, i.e. high school graduates who passed their baccalaureate exam. Because of this, a significant change in equity of access to higher education will be possible only after dealing with the shortcomings, and mitigating the social dividing trends in primary and secondary education, a measure which can bear fruits only in a 5-10 years' timeframe. For the near future, the main instruments to further social equity in higher education are need-based aid awards.

Due to the large degree of university autonomy in distributing national public funds for student support according to merit based and equity criteria, the authors considered institutional choices in the design of their scholarship disbursement policies as a proxy for the importance given to equity by Romanian universities. This is because under the current funding system the two-types of scholarships are funded jointly through the same funding line, thus creating a zero-sum game in which individual universities make the choice on how to distribute awards. On average, $85 \%$ from the public budget allocated for scholarships is distributed on merit based criteria, while only $15 \%$ aim at supporting the vulnerable groups.

In the Romanian context, the scholarship system is a relevant instrument for the purpose of enhancing participation of under-represented groups. Nationally, social disparities between students are not being diminished. On the contrary, large differences can be observed regarding access and success of students, based on their socio-economic background, residence area or disability status. Only $4.62 \%$ from the state budgeted students are supported through the need based aid system, even though the demand for need based aid from low-income families is clearly much higher. In addition, at current rates such awards fall well short of the minimum amount required to cover meals and accommodation.

While it is true that there has been a slight trend towards allocating a larger share scholarship funds for need-based aid over the past five years, it is obvious that this change is too small to have a significant impact in improving equity in Romanian universities. At present, it is unrealistic to expect a bolder change of priorities in university behaviour. In order to allow for the scholarships system to become more effective in terms of helping the under-represented groups, the system would need either a significant increase of the total student scholarship fund, a national regulation regarding the allocation of a larger share for need based aid, or a combination of the two. 


\section{Data used}

PIRLS and TIMSS database, 2011

National Institute of Statistic, 2014

National Council for Higher Education Funding, 2013

Ministry of National Education, 2014.

Open Access This chapter is distributed under the terms of the Creative Commons Attribution Noncommercial License, which permits any noncommercial use, distribution, and reproduction in any medium, provided the original author(s) and source are credited.

\section{References}

Bohle, D., \& Greskovits, B. (2012). Capitalist Diversity on Europe's Periphery. Ithaca: Cornell University Press.

Comunique of the meeting of European Ministers in charge of Higher Education. (2001). Towords the European Higher Education Area. Prague.

Comunique of the meeting of European Ministers in charge of Higher Education. (2005). Bergen.

Comunique of the meeting of European Ministers in charge of Higher Education. (2007) Towards the European Higher Education Area: responding to challenges in a globalised world. London.

Comunique of the meeting of European Ministers in charge of Higher Education. (2009). The Bologna Process 2020-The European Higher Education Area in the new decade. Leuven and Louvain-la-Neuve.

Comunique of the meeting of European Ministers in charge of Higher Education. (2012). Bucharest.

Eurostudent. (2008). Social and Econimic Conditions of Student Life in Europe: Eurostudent.

Geven, K. (2012). "Equity of what?" Understanting Policy for equity in higher education.

Government of Romania. (2012). Bologna Process Implementation Report. Bucharest: Bologna Process Secretariat.

Haj, C. (2014). Equity versus quality in higher education policies.

HDR. (2010). Human Development Report 2010. The Real Wealth of Nations: Pathways to Human Development. http://hdr.undp.org/sites/default/files/reports/270/hdr_2010_en_ complete_reprint.pdf

IEA, I. A. (2012a). PIRLs 2011 International Results in Reading. Chestnut Hill, MA, USA, Amsterdam, the Netherlands: TIMSS \& PIRLS International Study Center and International Association for the Evaluation of Educational Achievement (IEA).

IEA, I. A. (2012b). TIMSS 2011 International Results in Mathematics. Chestnut Hill, MA: TIMSS \& PIRLS International Study Center and International Association for the Evaluation of Educational Achievement (IEA).

ISE, Institute of Education Sciences. (2011). Report on the state of education.

Johnstone, D. B. (2010). Financing higher education worldwide: Who pays? Who should pay?. Baltimore: The Johns Hopkins University Press.

Link, B. G., \& Phelan, J. C. (1995). Social Conditions as Fundamental Causes of Disease. Journal of Health and Social Behavior, 80-94.

OECD. (2012). Education at a glance 2012: OECD indicators. Paris: OECD Publishing.

Proteasa, V., \& Miroiu, A. (2013). Are talents wisely spent? The case of student subsidise in Romanian Higher Education Higher Education Reforms in Romania: Between the Bologna Process and National Challanges. 
Romano, S. (2014). The Political and social construction of poverty: Central and East European countries in transition. Bristol: Policy Press.

Salmi, J., \& Hauptman, A. (2006). Innovations in tertiary education financing: A comparative evaluation of allocation mechanisms (Vol. Education Working Paper Series). Washington, D. C: World Bank.

Schwarz, S., \& Reheburg, M. (2004). Study costs and direct public student support in 16 European Countries-Towards a European Higher Education Area? European Journal of Education, 39 (4), 521-532.

Schwarzenberger, A. (2008). Public/private funding of higher education: a social balance. Hannover: HIS:Forum Hochschule.

Stiglitz, Joseph E. (2012). The price of inequality: How today's divided society endangers our future. New York: W.W. Norton \& Company.

Vila, L. E. (2000). The non-monetary benefits of education. European Journal of Education, 2132.

Voicu, B., \& Vasile, M. (2010). Rural-urban inequalities and expansion of tertiary education in Romania. Journal of Social Research and Policy, 5-24.

World Bank. (2007). Education Policy Note.

World Bank. (2011). Functional Review of the Higher Education Sector in Romania. Bucharest. 